\title{
Effect of Comorbidities and Choice of Fixation on the Onset of Bone Healing Time on Surgically Treated Intertrochanteric Femoral Fractures
}

\author{
Cerrahi Olarak Tedavi Edilen İntertrokanterik Femur Kırıklarında Eşlik Eden \\ Durumların ve Fiksasyon Seçiminin Kemik İyileşme Süresinin Başlangıcına Etkisi
}

\author{
D Alkan Bayrak, (D) Altuğ Duramaz \\ University of Health Sciences Turkey, Bakirköy Dr. Sadi Konuk Training and Research Hospital, Clinic of Orthopedics and Traumatology, \\ İstanbul, Turkey
}

\begin{abstract}
Objective: This study aimed to evaluate whether comorbidities affect the onset of bone healing time (BHT) in surgically treated intertrochanteric femoral fractures (IFFs).

Methods: The study comprised 55 patients (12 male and 43 female) who underwent surgical treatment of IFFs. The mean age of patients was $79.29 \pm 81.13$ years. The fractures were classified according to the AO Classification. Twenty-one patients were treated with dynamic hip screw, 15 with an external fixator, and 19 with proximal femoral nail. Thirty-one patients had comorbidities such as diabetes and hypertension.

Results: Patients were divided into three groups according to the BHT. Group 1 had BHT<30 days (G1), group 2 had BHT 30-60 days (G2), and group 3 had BHT $>60$ days (G3). There were no statistically significant differences among the groups in terms of age, sex, additional disease, and the fixation method. There were statistically significant differences among the groups in terms of receiving intensive care unit (ICU) treatment. The rates of ICU referral in G3 were significantly higher than those in G1, statistically close to being meaningfully higher than those in G2. Discharge duration was close to being meaningful in patients with more than one comorbidity.
\end{abstract}

Conclusion: Fixation type, age, and comorbidities did not affect BHT. Patients with more than one comorbidities had long hospitalization time owing to their prolonged preoperative surgical preparation time and postoperative evaluation of comorbidities.

Keywords: Intertrochanteric femoral fractures, fracture healing, fixation method, proximal femoral nail, dynamic hip screw

\section{öz}

Amaç: Bu çalışmanın amacı intertrokanterik femur kırıkları (IFK) olan hastaların cerrahi tedavisinde komorbiditelerin ve fiksasyon yöntemlerinin, kaynamaya başlama süresini (KBS) etkileyip etkilemediğini değerlendirmektir.

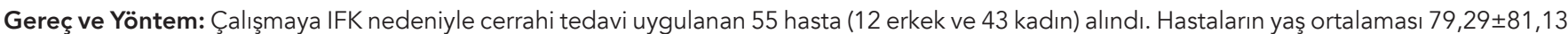
yıl (61,6 ile 91,5 yıl arasında değişmekteydi). Kırıklar AO sınıflamasına göre sınıflandırıldı. Yirmi bir hasta dinamik kalça vidası (DHS) ile tedavi edildi, 15 hasta eksternal fiksatör (EF) ile tedavi edildi, 19 hasta proksimal femoral çivi (PFN) ile tedavi edildi. Otuz bir hastanın diyabet, hipertansiyon vb. gibi ek hastalıkları vardı.

Bulgular: Hastalar kaynamaya başlama süresine göre üç gruba ayrıldı. KBS'si <30 gün grup 1 (G1), $30-60$ gün grup 2 (G2),>60 gün grup 3 (G3) olarak değerlendirildi. Gruplar arasında (G1, G2, G3) yaş, cinsiyet, ek hastalık ve fiksasyon yöntemi açısından istatistiksel olarak anlamlı bir fark saptanmadı. Gruplar arasında postoperatif dönemde yoğun bakım ünitesine (YBÜ) refere edilme oranı açısından istatistiksel olarak anlamlı farklar vardı. G3'te YBÜ refere edilme oranları G1'den anlamlı olarak yüksekti, istatistiksel olarak G2'den anlamlılığa yakın yüksekti. Birden fazla komorbiditesi olan hastaların hastanede yatış süresi diğer hastalardan anlamlıı̆̆a yakın derecede yüksekti.

Sonuç: Fiksasyon tipi, yaş ve komorbiditelerin KBS'sini etkilemediği gözlenmiştir. Birden fazla komorbiditesi olan hastaların, uzun preoperatif cerrahi hazırlık süresi ve ek hastalıkların postoperatif dönemde kontrol edilmesi nedeniyle hastanede yatma sürelerinin daha uzun olduğu gözlendi.

Anahtar Kelimeler: İntertrokanterik femur kırıkları, kırık iyileşmesi, fiksasyon tekniği, proksimal femoral çivi, kayan kalça vidası

Address for Correspondence: Alkan Bayrak,

University of Health Sciences Turkey, Bakirköy Dr. Sadi Konuk Training and Research Hospital, Clinic of Orthopedics and

Traumatology, İstanbul, Turkey

Phone: +90 5079489190 E-mail: drqueum@gmail.com ORCID ID: orcid.org/0000-0003-0189-1645

Cite as: Bayrak A, Duramaz A. Effect of Comorbidities and Choice of Fixation on the Onset of Bone Healing Time on Surgically Treated

Intertrochanteric Femoral Fractures. Med J Bakirkoy 2021;17:173-178

Received: 29.09 .2020

Accepted: 05.08.2021 


\section{INTRODUCTION}

Intertrochanteric femur fractures (IFFs) are common in elderly patients, especially in post-menopausal women, usually due to low-energy trauma such as simple falls (1). However, these can also occur in young patients following high-energy trauma, such as vehicle injuries (2). In the near future, the geriatric population will probably increase, and the incidence of osteoporotic bone fractures will be seen in orthopedic practice. In 1990, $26 \%$ of all hip fractures occurring in Asia were IFFs; however, this incidence is expected to reach $37 \%$ in 2025 and $45 \%$ in 2050 (3). The goal of treating IFFs is to ensure stable fixation for early mobilization and return to pre-fracture activity levels. Early mobilization is important for preventing complications, such as deep vein thromboembolism and decubitus ulcers, as well as for improving patient functions (4).

Patients with IFFs are at a risk of significant morbidity and high mortality $(5,6)$. In elderly patients, IFFs are usually associated with comorbidities such as diabetes; hypertension; pulmonary, renal, and cardiac conditions (7). Early reduction and stable surgical fixation of these fractures prevent complications such as avascular necrosis and nonunion as well as allows early mobilization (8). Comorbidities increase the risk of surgery in these patients.

Previous studies on IFFs usually examined the effect of fixation techniques on aspects such as union, stabilization, and weight-bearing time $(7,8)$. This retrospective study aimed to evaluate whether comorbidities have an effect on the onset of bone healing time after the surgical treatment of IFFs. In addition, we hypothesized that patients with comorbidities have a delayed onset of healing time.

\section{METHODS}

All patients who underwent surgical correction for IFFs between January 2014 and January 2015 were retrospectively investigated after the University of Health Sciences Turkey, Bakirköy Dr. Sadi Konuk Training and Research Hospital Approval of the Local Ethics Committee (IRB approval no: 2015/16/10). Data were collected both from patient files and electronic medical records. Age, sex, length of hospital stay, concomitant disease, discharge disposition, intensive care requirement, and fixation type were evaluated based on patient medical records (Table 1). Inclusion criteria were as follows: age $>60$ years; closed fractures; closed reduced fractures; AO-31-A1, A2, and B3 fracture types; unilateral fractures; anatomic or near anatomic reduction; and no accompanying lower limp fracture. Exclusion criteria were as follows: age <60 years; undergone hemiarthroplasty; pathological fractures; AO-31-A3, B1-2 type fractures; open fractures; accompanying lower limp fracture; nonanatomic reduction; and reoperated patients. Standard preoperative planning was conducted. Radiographs of the pelvis with both hips anteroposterior and the lateral view were obtained to confirm the diagnosis. Dynamic hip screw $(\mathrm{DHS})$, proximal femoral nail (PFN), or external fixation (EF) were the commonly used methods for IFF fixation. Materials for use during surgery were selected according to the surgeons' preference. All three fixation materials are frequently used in our clinic and daily orthopedic practice. No specific selection criteria were used. All IFFs were performed by closed reduction using traction table and C-arm fluoroscopy. The reduction criteria were based on the study by Fogagnolo et al. (9). Patients were mobilized on the postoperative day 2. The PFN group was subjected to full weight-bearing during the early postoperative period. The DHS and EF groups were subjected to only partial weight-bearing. Sutures were removed on the $14^{\text {th }}$ or $15^{\text {th }}$ day. $X$-rays were obtained in the $2^{\text {nd }}$ week and $1^{\text {st }}, 2^{\text {nd }}, 3^{\text {rd }}, 6^{\text {th }}$, and $12^{\text {th }}$ month postoperatively. Three

\begin{tabular}{|c|c|c|c|}
\hline & & Min-Max & Mean \pm SD \\
\hline \multicolumn{2}{|l|}{ Age (years) } & $61.6-91.5$ & $79.29 \pm 81.13$ \\
\hline \multirow{2}{*}{\multicolumn{2}{|c|}{ Hospitalization (days) }} & $2-28$ & $15 \pm 6.74$ \\
\hline & & $\mathrm{n}$ & $\%$ \\
\hline \multirow[b]{2}{*}{ Sex } & Female & 43 & 78.2 \\
\hline & Male & 12 & 21.8 \\
\hline \multirow{4}{*}{$\begin{array}{l}\text { AO } \\
\text { classification }\end{array}$} & 31.A1.2 & 30 & 54.5 \\
\hline & 31.A1.3 & 9 & 16.3 \\
\hline & 31.A2.2 & 10 & 18.2 \\
\hline & $31 . \mathrm{B3}$ & 6 & 11 \\
\hline \multirow[b]{7}{*}{ Comorbidities } & Hypertension & 16 & 29.1 \\
\hline & Diabetes & 7 & 12.7 \\
\hline & Chronic renal failure & 4 & 7.2 \\
\hline & Cardiac disease & 4 & 7.2 \\
\hline & Cancer & 3 & 5.5 \\
\hline & COPD & 2 & 3.6 \\
\hline & Alzheimer's disease & 3 & 5.5 \\
\hline \multirow{4}{*}{ ASA score } & 1 & 4 & 7.2 \\
\hline & 2 & 45 & 82 \\
\hline & 3 & 5 & 9 \\
\hline & 4 & 1 & 1.8 \\
\hline
\end{tabular}

ASA: American society of anesthesiology, COPD: Chronic obstructive pulmonary disease, SD: Standard deviation, Min-Max: Minumum-maximum 
orthopedic surgeons (with at least 10 years' experience in trauma surgery) reviewed preoperative and postoperative anteroposterior and lateral X-ray reports of each patient. The surgeons consensually decided the onset of healing time, according to callus formation on anteroposterior and frog-leg hip X-rays. The union times of IFFs were evaluated radiologically and clinically. The surgeons noted the healing time. The callus formation on three cortices was used for determining healing time. Clinical findings such as joint motion and pain with weight-bearing were collected from patient medical records.

Patients were divided into three groups according to the onset of union time. The postoperative radiographs of patients were evaluated, and the onset of union time was recorded. Radiographic evaluations included callus formation on the fracture side, shortening of the femoral neck length, lateral migration of the helical screw, and cortical thickening of the fracture site. The radiological finding of fracture healing was first observed at $<30$ days in the first group (G1), 30-60 days in the second group (G2), and $>60$ days in the third group (G3).

\section{Statistical Analysis}

Statistical analysis was performed using the NCSS (Number Cruncher Statistical System) 2007 (Kaysville, Utah, USA). Many-Whitney $U$ test was performed for descriptive statistical method evaluation (average, standard deviation, median, frequency, ratio, minimum, and maximum) and for comparing non-normally distributed data. Kruskal-Wallis test was used for comparing non-normally distributed quantitative data of three and upper groups. Bonferroni correction Dunn's test for conducted for determining the diversity group. Pearson ki-square test, Fisher-FreemanHalton test, Fisher's Exact test, and Yates were used for qualitative data comparison. P-values were considered statistically significant when $p<0.01$ and $p<0.05$.

\section{RESULTS}

The demographic features of study patients are presented in Table 1. Thirteen patients had one comorbidity and 18 had more than one comorbidity. Twenty-one patients were operated with DHS, 15 with EF, and 19 with PFN. Four patients were referred to the critical care unit. There were no statistically significant differences among the groups (G1, G2, G3) in terms of age, sex, additional disease, and the fixation method $(p=0.377, p=0.373$, and $p=0.792$, respectively). Interobserver There were statistically significant differences among the groups in terms of receiving intensive care $(p=0.021)$. According to post-hoc binary comparisons made to identify the group that was responsible for the difference, the rates of intensive care referral in G3 were significantly higher than those in G1 $(p=0.026)$, statistically close to being meaningfully higher than those in $G 2$ ( $p=0.055 ; p>0.05)$, and no difference in $\mathrm{G} 1$ and $\mathrm{G} 2(\mathrm{p}=1.000)$ (Table 2). According to the type of fixation and additional disease, there were no statistically significant differences in the rate of referral to the intensive care unit (ICU) ( $p=0.183$ and $p=0.123$, respectively) (Table 3 ). The time interval between the operation to discharge day and ICU referral showed a statistically significant difference in terms of the onset of bone healing ( $p=0.0021$ and $p=0.041$, respectively) (Table 4). There was no statistically significant relationship of the number of comorbid diseases with the onset of healing and ICU referral. The duration of discharge had close to statistically significant difference between patients who have only one and more than one comorbidities ( $p=0.053$ ) (Table 5).

Table 2. Post-hoc binary comparisons in terms of intensive care referral and discharge day

\begin{tabular}{llll}
\hline & $\begin{array}{l}<30 \text { days } \\
30-60 \text { days }\end{array}$ & $\begin{array}{l}<30 \text { days } \\
>60 \text { days }\end{array}$ & $\begin{array}{l}30-60 \text { days } \\
>60 \text { days }\end{array}$ \\
\hline $\begin{array}{l}\text { aaDischarge day } \\
\text { (day) }\end{array}$ & 1.000 & 0.084 & $0.048^{\star}$ \\
\hline $\begin{array}{l}\text { bb Intensive care } \\
\text { referral }\end{array}$ & 1.000 & $0.026^{*}$ & 0.055
\end{tabular}

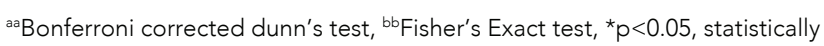
significant $p$ values were marked bold

Table 3. The relationship between referral to intensive care unit and comorbidities and types of fixation

\begin{tabular}{|c|c|c|c|c|}
\hline & & \multicolumn{2}{|l|}{ Intensive care } & \multirow[b]{2}{*}{$p$} \\
\hline & & $\begin{array}{l}\text { Not referred } \\
\mathrm{n}(\%)\end{array}$ & $\begin{array}{l}\text { Referred } \\
\mathrm{n}(\%)\end{array}$ & \\
\hline \multirow{2}{*}{ Comorbidities } & No & $24(100)$ & $0(0)$ & \multirow{2}{*}{$\mathrm{d} 0.123$} \\
\hline & Yes & $27(87.1)$ & $4(12.9)$ & \\
\hline \multirow{3}{*}{$\begin{array}{l}\text { Type of } \\
\text { fixation }\end{array}$} & DHS & $21(100)$ & $0(0)$ & \multirow{3}{*}{${ }^{\mathrm{b}} 0.185$} \\
\hline & $\mathrm{EF}$ & $13(86.7)$ & $2(13.3)$ & \\
\hline & PFN & $17(89.5)$ & $2(10.5)$ & \\
\hline
\end{tabular}

${ }^{b}$ Fisher-Freeman-Halton test, 'Fisher's Exact test, DHS: Dynamic hip screw, EF: External fixation, PFN: Proximal femoral nail

\section{DISCUSSION}

The key question we raised in the introduction of this study was whether there were any effects of comorbidities on the healing IFFs. We hypothesized that a delayed onset of callus formation occurs in patients with comorbidities. In the three groups, there were no statistical differences at the beginning of the callus formation. We did not observe 


\begin{tabular}{|c|c|c|c|c|c|}
\hline \multirow{2}{*}{$<30$ days $(n=33)$} & & \multicolumn{3}{|c|}{ Onset of bone healing } & \multirow{2}{*}{$p$} \\
\hline & & $30-60$ days $(n=13)$ & $>60$ days $(n=9)$ & & \\
\hline \multirow{3}{*}{ Type of fixation } & DHS & $13(39.4)$ & $7(53.8)$ & $1(11.1)$ & \multirow{3}{*}{ b0.332 } \\
\hline & EF & $8(24.2)$ & $3(23.1)$ & $4(44.4)$ & \\
\hline & PFN & $12(36.4)$ & $3(23.1)$ & $4(44.4)$ & \\
\hline \multirow{2}{*}{ Intensive care unit } & Not referred & $32(97.0)$ & $13(100)$ & $6(66.7)$ & \multirow{2}{*}{ ' 0.021 * } \\
\hline & Referred & $1(3.0)$ & $0(0)$ & $3(33.3)$ & \\
\hline \multirow{2}{*}{$\begin{array}{l}\text { Time interval between operation to } \\
\text { discharge day }\end{array}$} & Min-Max (median) & $1-25(4)$ & $1-10(5)$ & $0-9(2)$ & \multirow{2}{*}{${ }^{\mathrm{a}} 0.041$ * } \\
\hline & Mean \pm SD & $6.00 \pm 6.28$ & $5.23 \pm 2.98$ & $2.44 \pm 2.79$ & \\
\hline \multirow{2}{*}{$\begin{array}{l}\text { Time interval between admission and } \\
\text { discharge day }\end{array}$} & Min-Max (median) & $0-28(12)$ & $2-27(11)$ & $10-26(17)$ & \multirow{2}{*}{${ }^{\mathrm{a}} 0.102$} \\
\hline & Mean \pm SD & $12.73 \pm 6.48$ & $13.69 \pm 8.76$ & $17.67 \pm 4.64$ & \\
\hline
\end{tabular}

${ }^{a}$ Kruskal-Wallis $\mathrm{H}$ test, ${ }^{b}$ Fisher-Freeman-Halton test, ${ }^{\star} \mathrm{p}<0.05$, statistically significant $\mathrm{p}$ values were marked bold, DHS: Dynamic hip screw, EF: External fixation, PFN: Proximal femoral nail, SD: Standard deviation, Min-max: Minumum-maximum

Table 5. Comparison of time of bone healing. duration of intensive care, and discharge period according to the count of the comorbid disease

\begin{tabular}{|c|c|c|c|c|}
\hline & & \multicolumn{2}{|c|}{$\begin{array}{l}\text { Count of the } \\
\text { comorbid disease }\end{array}$} & \multirow[b]{2}{*}{$p$} \\
\hline & & $\begin{array}{l}1 \text { disease } \\
(n=13)\end{array}$ & $\begin{array}{l}>1 \\
\text { disease } \\
(n=18)\end{array}$ & \\
\hline \multirow{3}{*}{$\begin{array}{l}\text { Beginning of } \\
\text { healing (day) }\end{array}$} & $<30$ days & 7 (53.8) & $11(61.1)$ & \multirow{3}{*}{${ }^{\mathrm{b}} 0.423$} \\
\hline & 30-60 days & $2(15.4)$ & $5(27.8)$ & \\
\hline & $>60$ days & $4(30.8)$ & $2(11.1)$ & \\
\hline \multirow{2}{*}{$\begin{array}{l}\text { Intensive } \\
\text { care }\end{array}$} & Not referred & $10(76.9)$ & $17(94.4)$ & \multirow{2}{*}{$\mathrm{d} 0.284$} \\
\hline & Referred & $3(23.1)$ & $1(5.6)$ & \\
\hline \multirow{2}{*}{$\begin{array}{l}\text { Duration of } \\
\text { discharge } \\
\text { (day) }\end{array}$} & $\begin{array}{l}\text { Min-max } \\
\text { (median) }\end{array}$ & $0-9(3)$ & 2-25 (4) & \multirow[t]{2}{*}{$\mathrm{e} 0.053$} \\
\hline & Mean \pm SD & $3.31 \pm 2.81$ & $7.11 \pm 6.60$ & \\
\hline
\end{tabular}

bFisher-Freeman-Halton test, ' 'Fisher's Exact test, eMann-Whitney $U$ test, SD: Standard deviation, Min-max: Minumum-maximum

any effects of additional diseases such as diabetes mellitus, coronary artery disease, and chronic renal failure. These comorbidities affect the duration of hospitalization. There was no statistical relationship between comorbidities and ICU referral, but all patients referred to ICU had comorbidities. Patients who had more than one additional disease had a longer hospital duration than the others. Bennett et al. (10) emphasized that hospitalization time was delayed in older patients who had an additional disease and proximal femoral fracture. The duration of admission time to surgical time is delayed in these patients because they require additional disease management such glucose regulation and waiting for lack of bed in the ICU (2).
DHS has been used for a long time for ensuring stable extra-capsular intertrochanteric femoral fractures (11). Reportedly, DHS has increased the failure rate of unstable fractures and reverse obliquity fractures $(12,13)$. PFN is also used for treating proximal femoral fractures. PFN was developed by AO/ASIF for proximal femoral fractures for preventing gamma nail complications (14). A $6.5 \mathrm{~mm}$ antirotation hip screw decreases the incidence of implant cutout, and a smaller diameter and fluting of the tip of the nail reduces the distal forces, which can prevent distal femoral fractures (15). EF is a fast and minimally invasive method for IFF stabilization (16). EF is used for reducing surgery duration and intraoperative bleeding. Edipoğlu et al. (17) reported that EF reduces surgery time and intraoperative bleeding compared to PFN and DHS. DHS, PFN, and EF are minimally invasive methods for fixation of proximal femur fractures, and these methods do not dramatically increase surgical damage (18). In our study, there was no statistical relationship between the onset of callus formation and fixation type. We believe that there was no difference between the onset of union time because the three fixation types provide similar and essential stability for bone healing. In addition, ICU referral was not related to the type of fixation. Patients in the three groups did not differ in terms of age, sex, and mean duration of hospitalization stay. As the three fixation types used are minimally invasive surgical procedures, their effect on the medical status of the patients and the referral of ICU was similar.

Reportedly, comorbidities decreased soft tissue nutrition (19). In our study of older patients with comorbidities, we observed that this decreased soft tissue nutrition did not affect the onset of healing because the hip joint was 
covered with sufficiently thick soft tissue and because the fixation types were stable. We noted delayed union in patients who were admitted to the ICU. Patients who were referred to ICU have limitations for mobility, and we believe this causes delayed union. However, we could not observe any relationship between the admission of patients with multiple comorbidities to the ICU. Multiple comorbid diseases result in higher ASA classifications. ASA 3 and 4 patients require longer hospitalization time from admission to surgery (20).

In the current study, patients with comorbidities had longer hospitalization stays. Additional diseases and older age result in long-term preparation of patients, especially before surgery $(21,22)$. In patients with comorbidities, the risk of referral to ICU is increased; similarly, massive blood loss is noted in the postoperative period (22-24). The present study also showed that patients with comorbidities were hospitalized for longer periods due to preoperative preparation and postoperative care period. We consider that a multidisciplinary evaluation is necessary for such patients, which ultimately prolongs hospitalization.

\section{Study Limitations}

The limitations of the study were its retrospective design, a relatively small number of patients, and no randomization. In contrast, the strength of the study is in its contribution to the limited number of studies investigating the effect of comorbid diseases on fracture healing with different fixation techniques.

\section{CONCLUSION}

There is no relationship between the onset time of union and comorbidities. However, we detected a delay of the onset of union time in patients who were referred to the ICU and noted a longer hospital stay in patients with more than one comorbidities.

\section{ETHICS}

Ethics Committee Approval: The study were approved by the Local Ethics Committee of University of Health Sciences Turkey, Bakirköy Dr. Sadi Konuk Training and Research Hospital (IRB approval no: 2015/16/06).

Informed Consent: Informed consent was obtained from all individual participants included in the study.

\section{Authorship Contributions}

Surgical and Medical Practices: A.B., A.D., Concept: A.B., A.D., Design: A.B., A.D., Data Collection or Processing: A.B., A.D., Analysis or Interpretation: A.B., A.D., Literature Search: A.B., A.D., Writing: A.B., A.D.
Conflict of Interest: No conflict of interest was declared by the authors.

Financial Disclosure: The authors declared that this study received no financial support.

\section{REFERENCES}

1. Ju JB, Zhang PX, Jiang BG. Hip Replacement as Alternative to Intramedullary Nail in Elderly Patients with Unstable Intertrochanteric Fracture: A Systematic Review and Meta-Analysis. Orthop Surg 2019;11:745-54.

2. Gomes LP, do Nascimento LD, Campos TV, Paiva EB, de Andrade MA, Guimarães HC. Influence of age on delayed surgical treatment of proximal femoral fractures. Acta Ortop Bras 2015;23:315-18.

3. Melton LJ 3rd, Kearns AE, Atkinson EJ, Bolander ME, Achenbach SJ, Huddleston JM, et al. Secular trends in hip fracture incidence and recurrence. Osteoporos Int 2009;20:687-94.

4. Hu F, Jiang C, Shen J, Tang P, Wang Y. Preoperative predictors for mortality following hip fracture surgery: a systematic review and meta-analysis. Injury 2012;43:676-85.

5. Camurcu Y, Cobden A, Sofu H, Saklavci N, Kis M. What Are the Determinants of Mortality After Cemented Bipolar Hemiarthroplasty for Unstable Intertrochanteric Fractures in Elderly Patients? J Arthroplasty 2017;32:3038-43.

6. Cengiz Ö, Demir N, Dirvar F, Ceylan HH. Mortality and the Factors Affecting Patients Over 65 Age with Unstable Intertrochanteric Fractures Treated with Proximal Femoral Nail. Med J Bakirkoy 2018;14:403-7.

7. Jonnes C, Sm S, Najimudeen S. Type II Intertrochanteric Fractures: Proximal Femoral Nailing (PFN) Versus Dynamic Hip Screw (DHS). Arch Bone Jt Surg 2016;4:23-8.

8. Saul D, Riekenberg J, Ammon JC, Hoffmann DB, Sehmisch S. Hip Fractures: Therapy, Timing, and Complication Spectrum. Orthop Surg 2019;11:994-1002.

9. Fogagnolo F, Kfuri M Jr, Paccola CA. Intramedullary fixation of pertrochanteric hip fractures with the short AO-ASIF proximal femoral nail. Arch Orthop Trauma Surg 2004;124:31-7.

10. Bennett KM, Scarborough JE, Vaslef S. Outcomes and health care resource utilization in super-elderly trauma patients. J Surg Res 2010;163:127-31.

11. Mallya S, Kamath SU, Annappa R, Nazareth NE, Kamath K, Tyagi P. The Results of Unstable Intertrochanteric Femur Fracture Treated with Proximal Femoral Nail Antirotation-2 with respect to Different Greater Trochanteric Entry Points. Adv Orthop 2020;2020:2834816.

12. Cun Y, Dou C, Tian S, Li M, Zhu Y, Cheng $X$, et al. Traditional and bionic dynamic hip screw fixation for the treatment of intertrochanteric fracture: a finite element analysis. Int Orthop 2020;44:551-9.

13. Taheriazam A, Saeidinia A. Salvage of failed dynamic hip screw fixation of intertrochanteric fractures. Orthop Res Rev 2019;11:93-8.

14. Hoffmann MF, Khoriaty JD, Sietsema DL, Jones CB. Outcome of intramedullary nailing treatment for intertrochanteric femoral fractures. J Orthop Surg Res 2019;14:360.

15. Korkmaz MF, Erdem MN, Disli Z, Selcuk EB, Karakaplan M, Gogus A. Outcomes of trochanteric femoral fractures treated with proximal femoral nail: an analysis of 100 consecutive cases. Clin Interv Aging 2014;9:569-74.

16. Zheng N, Tang N, Qin L. Atypical femoral fractures and current management. J Orthop Translat 2016;7:7-22. 
17. Edipoğlu E, Bilgili MG, Sarı C, Başaran SH, Kural C, Avkan MC The Treatment Of Intertrochanteric Femur Fractures In Geriatric Patients With External Fixator. Med J Bakirkoy 2013;9:28-32

18. Arirachakaran $A$, Amphansap $T$, Thanindratarn $P$, Piyapittayanun $P$, Srisawat $P$, Kongtharvonskul J. Comparative outcome of PFNA, Gamma nails, PCCP, Medoff plate, LISS and dynamic hip screws for fixation in elderly trochanteric fractures: a systematic review and network meta-analysis of randomized controlled trials. Eur J Orthop Surg Traumatol 2017;27:937-52.

19. Bernaus M, Anglès F, Escudero B, Veloso M, Matamala A, FontVizcarra L. Subcutaneous Radiographic Measurement: A Marker to Evaluate Surgical Site Infection Risk in Elderly Hip Fracture Patients. J Bone Jt Infect 2019;4:27-32.

20. Ricci WM, Brandt A, McAndrew C, Gardner MJ. Factors affecting delay to surgery and length of stay for patients with hip fracture. $J$ Orthop Trauma 2015;29:e109-14.
21. Bayrak A, Bayrak SK, Duramaz A, Kızılkaya C, Seller A, Aslantaş FÇ. Demographic and clinical results of proximal femoral fractures. Acta Medica Alanya. 2017;1:145-8.

22. Kır G, Buget M, Koltka K, Kir MÇ, Pembeci K. The Impact of Timing of Surgery and the Anesthesia Technique in Hip Fracture Surgery on In-hospital Mortality and Length of Hospital Stay. J Acad Res Med 2020;10:82-7.

23. Ghaffar S, Pearse RM, Gillies MA. ICU admission after surgery: who benefits? Curr Opin Crit Care 2017;23:424-9.

24. Kelly-Pettersson P, Samuelsson B, Muren O, Unbeck M, Gordon M, Stark $A$, et al. Waiting time to surgery is correlated with an increased risk of serious adverse events during hospital stay in patients with hip-fracture: A cohort study. Int J Nurs Stud 2017;69:91-7. 